GSA Data Repository Item 2017147

Stockmeyer, J.M., Shaw, J.H., Brown, N.D., Rhodes, E.J., Richardson, P.W., Wang, M., Lavin, L.C., and Guan, S., 2017, Active thrust sheet deformation over multiple rupture cycles: A quantitative basis for relating terrace folds to fault slip rates: GSA Bulletin, doi:10.1130/B31590.1.

\title{
DATA REPOSITORY
}

Figure DR1

Figure DR2 


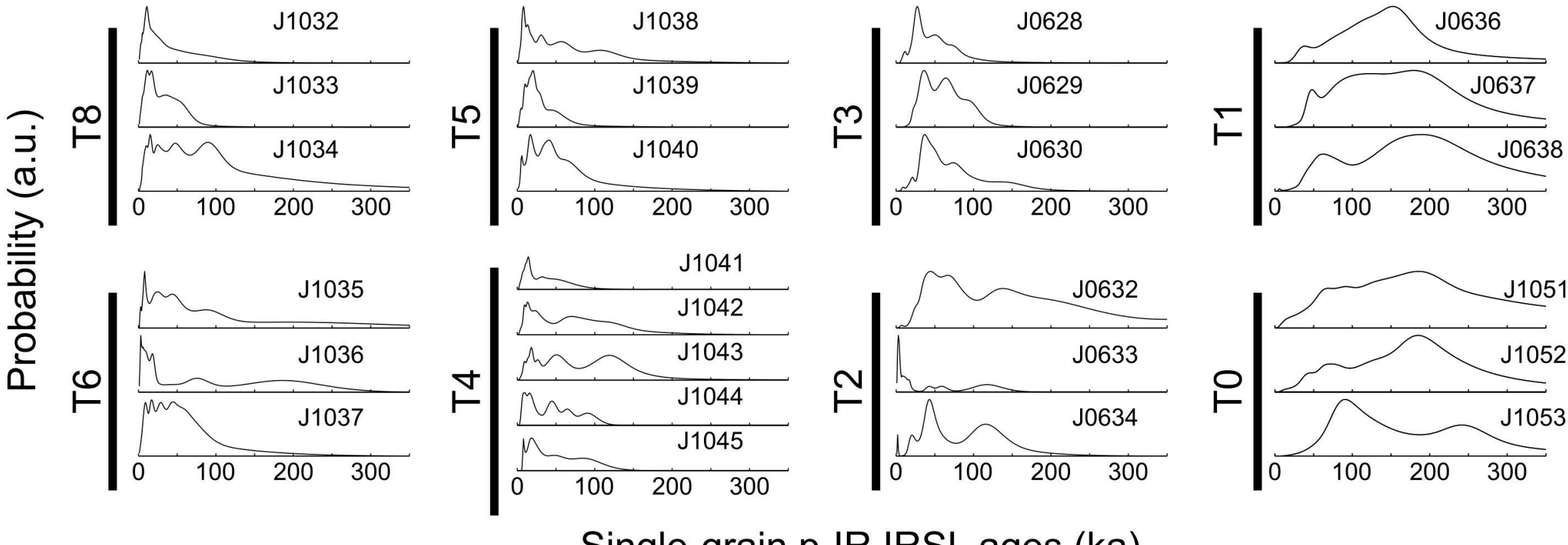

Single-grain p-IR IRSL ages (ka) 


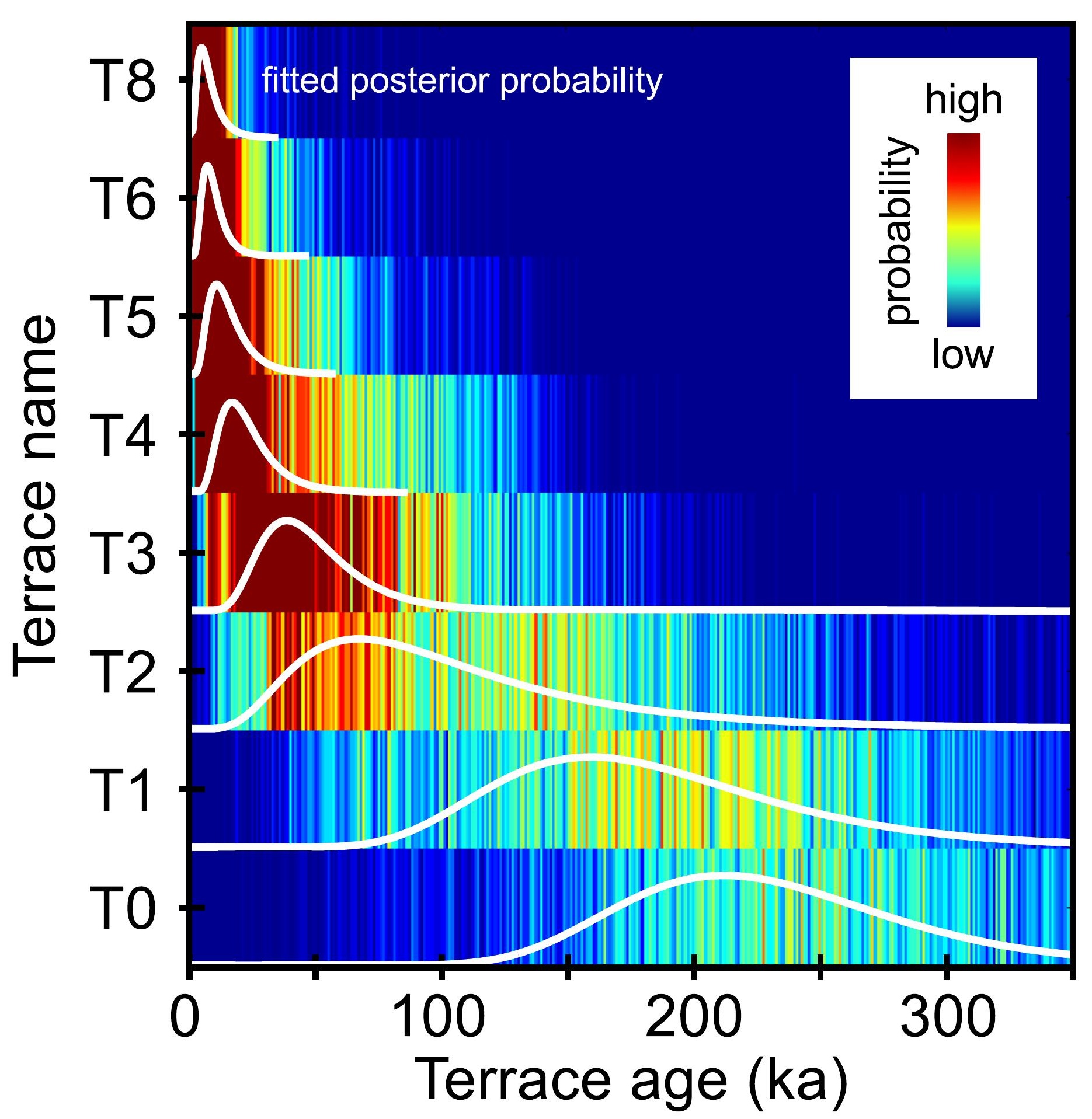

